\title{
遷移温度域での破壊じん性の簡易決定法†
}

岩 舘 忠 雄* 竹 俣 裕 行** 劉 世 程***

\section{Simplified Method for Determination of Fracture Toughness in Transition Temperature Region}

by

\author{
Tadao Iwadate*, Hiroyuki Takemata** and Shicheng LiU***
}

The fracture toughness $K_{J C}$ values of small specimens in the transition temperature region were analyzed to confirm the offset method standarized by JSPS 129 Committee. The offset method is a very useful method for the determination of lower-bound fracture toughness $K_{J C i}$ of material especially in the lower shelf temperature region where the stable crack growth is smaller than about $0.2 \mathrm{~mm}$. The $K_{J C i}$ values obtained from the offset method showed a good agreement with the $K_{I C}$ values of large specimens per ASTM E399 and the $K_{J C i}$ value from the fractography method standarized by JSPS 129 Committee.

Key words : Elastic-plastic fracture, Fracture toughness, Transition region, J-integral, Testing technique

\section{1 緒言}

材料の破壊じん性の測定方法には, 上部棚温度域にお いては, JSME S001 およびASTM E813の J J 試験法 があり，遷移温度域においては，ASTM E399の $K_{I C}$ 試 験法がある。ここで, 遷移温度域を考えると, 大形試験 片を用いた $K_{I C}$ の測定は，試験費用や試験片採取などの 問題があり，破壊じん性の測定が不可能な場合が多い. 一方，小形試験片による破壊じん性の測定は， $J_{I C}$ 試験 の適用などが検討されているが，得られる破壊じん性の ばらつきが大きいという問題がある。

最近, 日本学術振興会第 129 委員会 (委員長 横堀武 夫）においては, 小形試験片を用いて遷移温度域におけ る破壊じん性の最小值を求める標準試験法として, 試験 片の破面観察に基づいたフラクトグラフイ法, また簡易 決定法としてのオフセット法を提案している. 本研究は, その学振第 129 委員会の推奨するオフセット法の提案の 背景となった研究であり，その研究内容について取りま とめ報告する.

\section{2 試験材および試験方法}

Table I に本研究で使用した原子炬圧力容器用鋼の $\mathrm{A} 508 \mathrm{C} 1.3$ 鋼および A533B 鋼の機械的性質を示す。こ こで，両鋼はともに学振第 129 委員会および米国の MPC (Material Properties Council) によって実施され
た国際共通試験に用いられた試験材であり，A533B 鋼 は不純物元素量を調整し，じん性值を極度に低くした材 料である. また ま, 本研究で提案したオフセット法と大形 試験片による $K_{I C}$ 試験の結果との比較には, Table I に 示すロー夕材の $\mathrm{A} 470 \mathrm{Ni}-\mathrm{Cr}-\mathrm{Mo}-\mathrm{V}$ 鋼を使用した。

試験片は $1 \mathrm{~T}-\mathrm{CT}$ 試験片を主に，20\%のサイドグル ーブを付与した $0.5 \mathrm{~T}, 1 \mathrm{~T}, 2 \mathrm{~T}, 4 \mathrm{~T}, 6 \mathrm{~T}$ の CT 試験片を 使用した，疲労予き裂は $a_{0} / W=0.50 \sim 0.65$ （ $a_{0}$ ：予き 裂長さ，W：試験片幅）とし, JSME S.001 および ASTM E813に従い挿入した。

試験は，変位制御によって試験片に荷重を負荷し破壊 させた. 試験片の個数は一温度につき 5 個以上とした. 破壊じん性 $K_{J C}$ は荷重一荷重点変位曲線から破壊時の $\mathrm{J}$ 積分を算出し，次式により $K_{J C}$ に変換した。

$$
K_{J C}=\left[J_{C} E /\left(1-\nu^{2}\right)\right]^{1 / 2}
$$

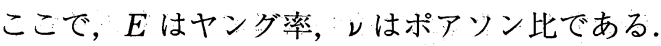

\section{3 遷移温度域での破壊じん性特性}

\section{$3 \cdot 1$ ：破壊じん性特性}

Fig. 1は国際共通試験での日本側の研究機関によって 得られた $\mathrm{A} 508 \mathrm{C} 1.3$ 鋼の破壊じん性試験の結果を示した ものであり, Fig. 2 は著者らの自主研究によって得られ た A533B 鋼の共通試験材の結果を示したものである. 破壊じん性 $K_{J C}$ のばらつきは両鋼とも高温側で大きく，

Table I. Mechanical properties of the steels used.

\begin{tabular}{c|c|c|c|c|c|c|c}
\hline Steels & $\sigma_{y s}(\mathrm{MPa})$ & $\sigma_{T s}(\mathrm{MPa})$ & El. $(\%)$ & R. A. $(\%)$ & FATT $\left({ }^{\circ} \mathrm{C}\right)$ & NDTT $\left({ }^{\circ} \mathrm{C}\right)$ & $\mathrm{CVN}-\mathrm{us}(\mathrm{J})$ \\
\hline A508Cl.3 & 456 & 599 & 24.8 & 75.9 & -15 & -30 \\
A533B & 504 & 692 & 20.2 & 52.0 & 50 & 245 \\
A470 & 644 & 766 & 23.5 & 63.0 & -2 & 70 \\
\hline
\end{tabular}




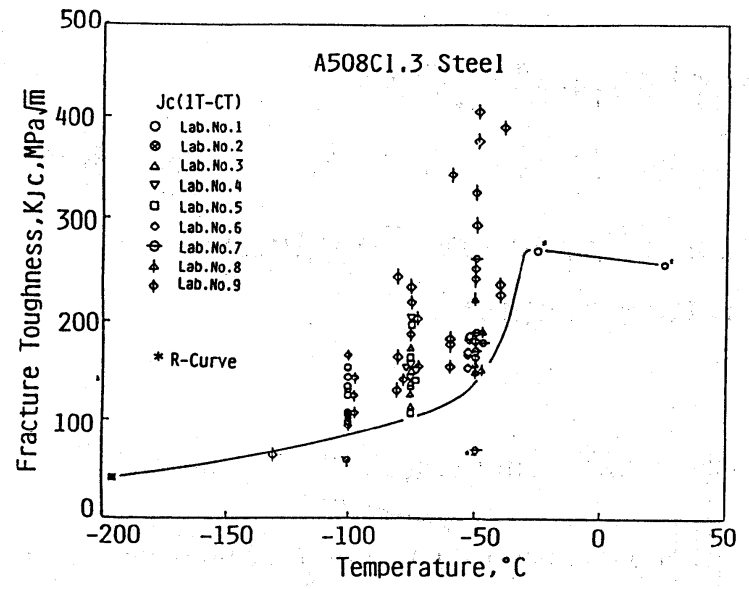

Fig. 1. Fracture toughness $K_{J C}$ values as a function of temperature for $\mathrm{A} 508 \mathrm{C} 1.3$ steel.

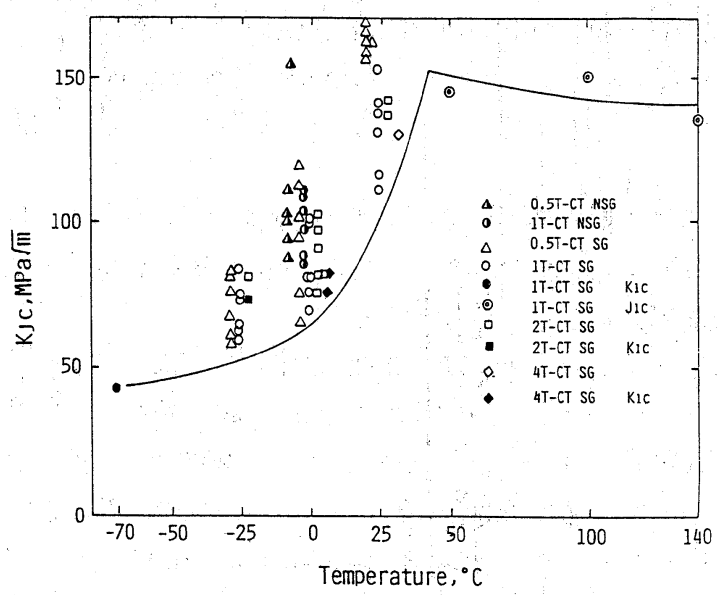

Fig. 2. Fracture toughness $K_{J c}$ values as a function of temperature for A533B steel.

かつ試験片寸法が小さくなるにつれて，ばらつきは大き くなる結果を示している.

Fig. 4 は破壊じん性のばらつきを検討するために，学 振第 129 委員会じん性試験小委員会において解析された 結果の一例である。すなわち，破壞した試験片の破面を 観察し, Fig. 3 に示す安定き裂長さ $\Delta a_{0}$, 安定き裂先端 からトリガーポイントまでの距離 $X$ および $\Delta a_{0}+X$ を 測定し，破壊じん性 $K_{J c}$ 值との関係で示したものである. 破壊時の $K_{J c}$ 值は $\Delta a_{0}, X$, 抢上び $\Delta a_{0}+X$ と良い相関 にあり，破壊じん性 $K_{J c}$ のばらつきは $\Delta a_{0}, X, \Delta a_{0}$ $+X$ の大きさによって支配されていることがわかる., この事実は後述の $4 \cdot 1$ 節に示す学振第 129 委員会の標 準試験法の一つであるフラクトグラフィ法の基礎となっ ている

\section{$3 \cdot 2$ 破壊じん性のばらつきとその下限值}

Fig. 5 は疲労き裂を付与した大形試験片および小形試 験片を荷重した場合の破壊過程を示したものである。荷 重の上昇にともないき裂先端はすべり鈍化し，やがてそ の鈍化域前方にボイドが発生する。ボイドはその後の荷 重で合体し安定き裂が発生する. 安定き裂の発生の後に, さらに荷重すると安定き裂は進展し，ある長さになった

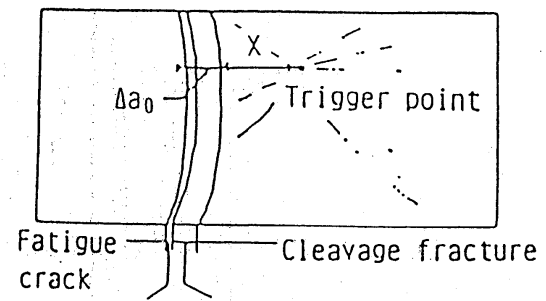

SZW Stable crack

Fig. 3. Schematic representation of $\Delta a_{0}, X$ and $\Delta a_{0}+X$.

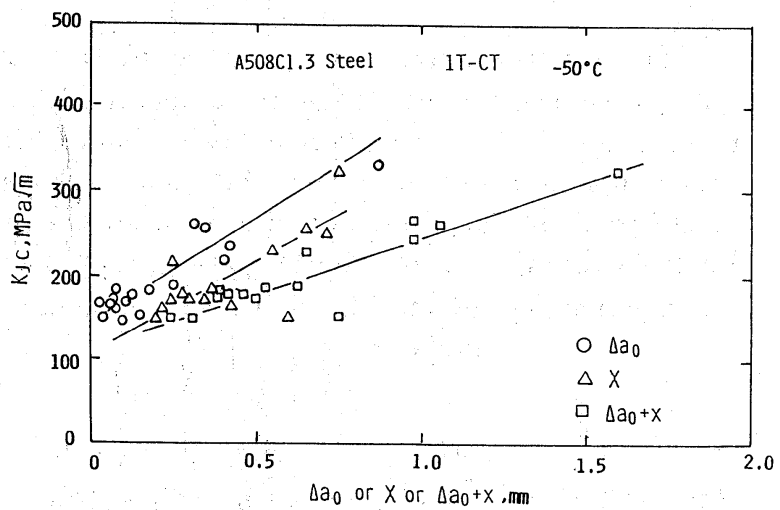

Fig. 4. $K_{J c} v s . \Delta a_{0}, K_{J c} v s . X$ and $K_{J c} v s . \Delta a_{0}+X$ relationships.

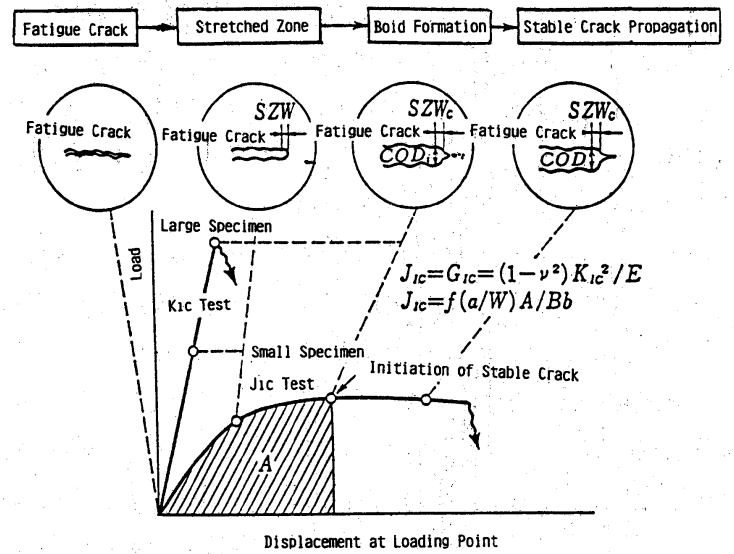

Fig. 5. Fracture process around a crack tip.

時に材料の不均一性に基づく最弱部を起点（トリガーポ イント）として，急速破壊を起こす．したがって，破壊 じん性のばらつきは, その急速破壞に至るまでに発達し た安定き裂長さ $\Delta a_{0}$ ，およびトリガーポイントまでの 距離 $X, \Delta a_{0}+X$ の差によって生ずる.

ここで, 小形試験片の場合には, 破壊のトリガーポイ ントとなる材料の最弱部が疲労予き裂前縁に含まれる確 率は小さく，またき裂先端周りの塑性拘束が小さいため に，大きなばらつきを示す. 移温度域においては試験片寸法が大きくなり十分な平面 ひずみの条件が満足されるようになるにつれ，急速破壊 の開始点は Fig. 5 にみるように安定き裂の発生とほほ時 期を同じくして起こり，破壊じん性のばらつきは小さく 
なる、このようなき裂先端での破壊過程から，破壊じん 性の最小值は安定き裂の発生開始時の破壊じん性によっ て定義されている.

$$
4 \text { フラクトグラフィ法によるデータ解析 }
$$

$4 \cdot 1$ フラクトグラフィ法の概要

学振第 129 委員会の標準試験法の一つであるフラクト グラフ.イ法の手順を以下に示す.

（1） 6 個の試験片を用いて所定の温度で破壊じん性試 験を行なう。

（2）試験片の破面の観察を行ない，ぜい性破壊の特徴 であるシェブロンパターンを逆にたどりながら破壊の起 点であるトリガーポイントを見つける.

(3) トリガーポイントおよびそのライン上で疲労予き 裂の前縁を含むように, 走査型電子顕微鏡を用いて拡大 写真を撮影し，Fig. 3 に示すように安定き裂長さ $\Delta a_{0}$, 安定き裂先端からトリガーポイントまでの距離 $X$, お よび $\Delta a_{0}+X$ を測定する.

(4) Fig. 6 の一例に示すように, $K_{J C}$ と $\Delta a_{0}+X$ の関 係のグラフ, 同様に $K_{J C}$ と $\Delta a_{0}$ の関係, $K_{J C}$ と $X$ の関 係のグラフを作成する.

（5）測定点にフィットするように直線近似を行ない, $\Delta a_{0}=0, X=0, \Delta a_{0}+X=0$ で定義される縦軸との交点 $K_{J C i Q}$ を決定する.

（6） その際， $\Delta a_{0}, X, \Delta a_{0}+X$ の最小值を示すデー 夕点 $\Delta a_{0 \min }, X_{\min }, \Delta a_{0}+X_{\min }$ は最大值を示すデー夕点 $\Delta a_{\text {omax }}, X_{\max }, \Delta a_{0}+X_{\max }$ の $1 / 2$ の值以下の範囲に入っ ていなければならない.

（7）また，直線近似から最も離れた点の $K_{J C}$ 值が，そ の直線とデー夕点との差が $K_{J C}$ 值（実線上の值）の $\pm 15 \%$ 以上離れている場合には, そのデータ点を除い て再度直線近似し, 得られた直線と縦軸との交点を $K_{J C i Q}$ とする.ここで, 直線近似のために必要なデータ 数は 4 個以上とする.

（8）このようにして決定される $\Delta a_{0} ， X$ および $\Delta a_{0}$ $+X$ に対応した $K_{J C i Q}$ 值の最小値が上記 (6), (7) の条件 を満足する場合において, 破壊じん性の最小值として有 効な $K_{J C i}$ 值と定義する.

\section{$4 \cdot 2$ フラクトグラフィ法の問題点}

Fig. 7 (a) は $-50^{\circ} \mathrm{C},-75^{\circ} \mathrm{C},-100^{\circ} \mathrm{C}$ で得られた $\mathrm{A} 508 \mathrm{C} 1.3$ 鋼の $K_{J C}$ と $\Delta a_{0}$ の関係および $K_{J C}$ と $\Delta a_{0}+X$ の関係，およびFig. 7 (b) は $25^{\circ} \mathrm{C}, 0^{\circ} \mathrm{C},-25^{\circ} \mathrm{C}$ で得ら

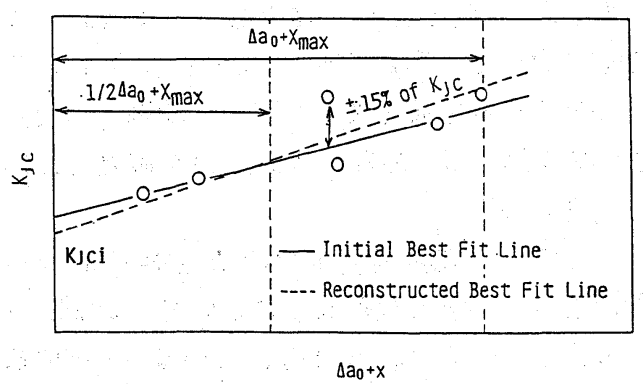

Fig. 6. Measurement of $K_{J C i}$ using the fractography method.
れた $\mathrm{A} 533 \mathrm{~B}$ 鋼の $K_{J c}$ と $\Delta a_{0}$ の関係および $K_{J C}$ と $\Delta a_{0}$ $+X$ の関係をまとめて示したものである.いずれの試 験温度においても $K_{J C}$ と $\Delta a_{0}$ および $\Delta a_{0}+X$ の関係は 明瞭に観察され, 破壊じん性 $K_{J C}$ の大きさやばらつきは 安定き裂長さ $\Delta a_{0}$ およびトリガーポイントまでの距離 $\Delta a_{0}+X$ の大きさに支配されていることがわかる.

ここで, 学振第 129 委員会のフラクトグラフィ法を考 えると, 下部棚温度域や A533B 鋼のように安定き裂長 さ $\Delta a_{0}$ が小さい場合には, その適用は精度上多分に問 題がある. すなわち $\Delta a_{0 \max }$ が小さい場合には, Fig. 7 にみるように, $K_{J c}$ と $\Delta a_{0}$ の関係は鈍化曲線上に位置す ることがあり, $K_{J C}$ と $\Delta a_{0}$ の関係を直線近似し, $\Delta a_{0}$ $=0$ によって決定される $K_{J C i}$ 值は大きなばらつきを与 え，場合によっては $K_{J C i}$ 值がゼロになることも予想さ れる. また $\Delta a_{0}$ が小さい場合には， $X$ および $\Delta a_{0}+X$ の值も極めて小さく, $K_{J C}$ と $X$ および $K_{J C}$ と $\Delta a_{0}+X$ との関係から $K_{J C i}$ を決定することは極めて難しい. さ らに, 試験片によっては, 破壊の起点であるトリガーポ イントを見つけるためのシェブロンパターンが観察され ない場合がある.

Fig. 8.はそのようなフラクトグラフィ法の測定精度を 検討するために, 学振第 129 委員会の共通試験によって

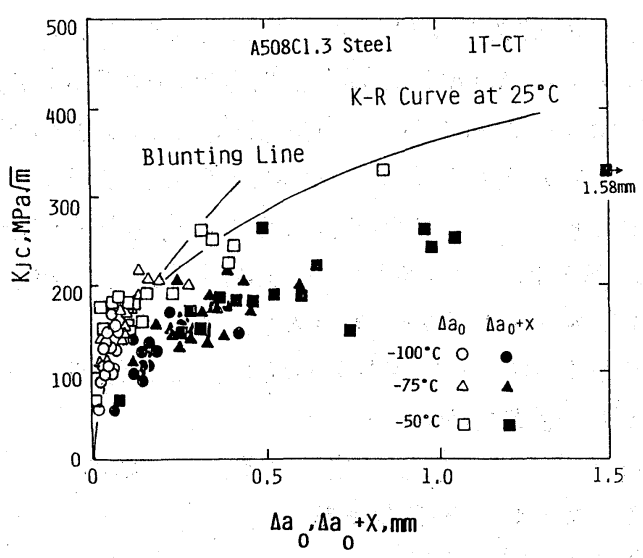

(a) A508C1.3 steel.

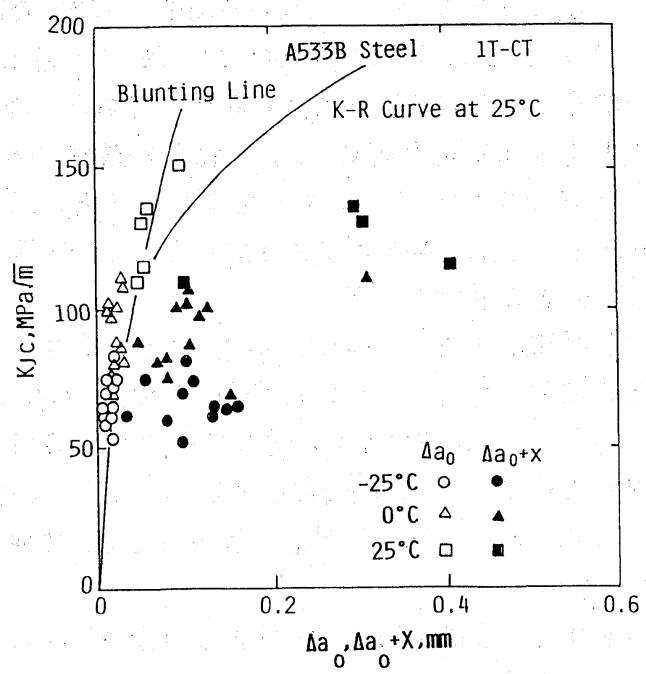

(b) A533B steel

Fig. 7. $K_{J c}$ vs. $\Delta a_{0}$ and $K_{J c}$ vs. $\Delta a_{0}+X$ relationships. 


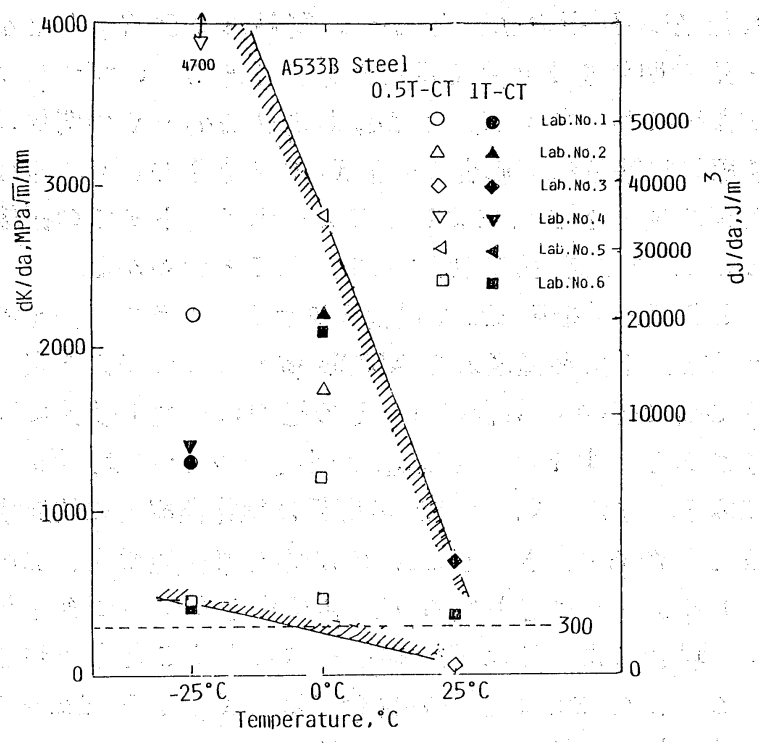

Fig. 8. Scatter of $d K / d a$ at different temperatures.

得られた A533B 鋼の試験結果において，各研究機関の $K_{J C}$ と $\Delta a_{0}$ の関係図の勾配 $d K / d a$ を温度ごとに示した ものである. 低温になるに従い $d K / d a$ の勾配は各研究 機関によって大きくばらついている.

Fig. 9 はそれらの $d K / d a$ を安定き裂長さの最大值 $\Delta a_{\max }$ との関係でプロットし直したものである.ここ で，図中には $\mathrm{A} 508 \mathrm{C} 1.3$ 鋼の結果もあわせて示した．勾 配 $d K / d a$ のばらつきは, 明らかに $\Delta a_{\max }$ が小さくな るにつれて大きくなることを示している. フラクトグラ フィ法においては，勾配のばらつきは得られる破壊じん 性 $K_{J C i}$ 值のばらつきを大ぎく支配する：したがって， 試験片に観察される安定き裂の長さ为小さく，また起点 までの距離 $\Delta a_{0}+X$ が小さい場合には, 他のデー夕解 析の方法が必要である.

\section{5 オフセット法によるデータ解析}

\section{$5 \cdot 1$ オフセット法の提案}

本研究の提案するオフセット法は, Fig. 6 のフラクト グラフィ法において $K_{J C}$ と $\Delta a_{0}$ の関係の勾配 $d K / d a$ あるいは $J_{c}$ と $\Delta a_{0}$ の関係の勾配 $d J / d a$ を一定と仮定 し, 破壊じん性の最小值を求める簡便法である. 本方法 は走査型電子顕微鏡 $(\mathrm{SEM})$ による破面の観察が不要で あり，除荷コンプライアンス法を用いることにより， $K_{J C i}$ 值あるいは $J_{C i}$ 值を容易に決定することが可能であ る. 以下にその手順を示す.

(1) 上部棚温度域において, $\mathrm{J}$ 積分と安定き裂長さ $\Delta a_{0}$ との関係で示される $J-R$ 曲線を求め，Fig. 10 (a) に示すように $\Delta a_{0}=0.2 \mathrm{~mm}$ の位置で原点から $R$ 曲線へ の接線と平行にオフセット線を引く.ここで, $J-R$ 曲 線の代りに, $K_{J}$ と $\Delta a_{0}$ の関係で示される $K-R$ 曲線を 用いても良い.

(2) オフセット線と $J-R$ 曲線あるいは $K-R$ 曲線と の交点で, $R$ 曲線に対する接線を引き，その傾き $n$ を 求める.

（3）遷移温度域の所定の試験温度で 6 個の試験片を用

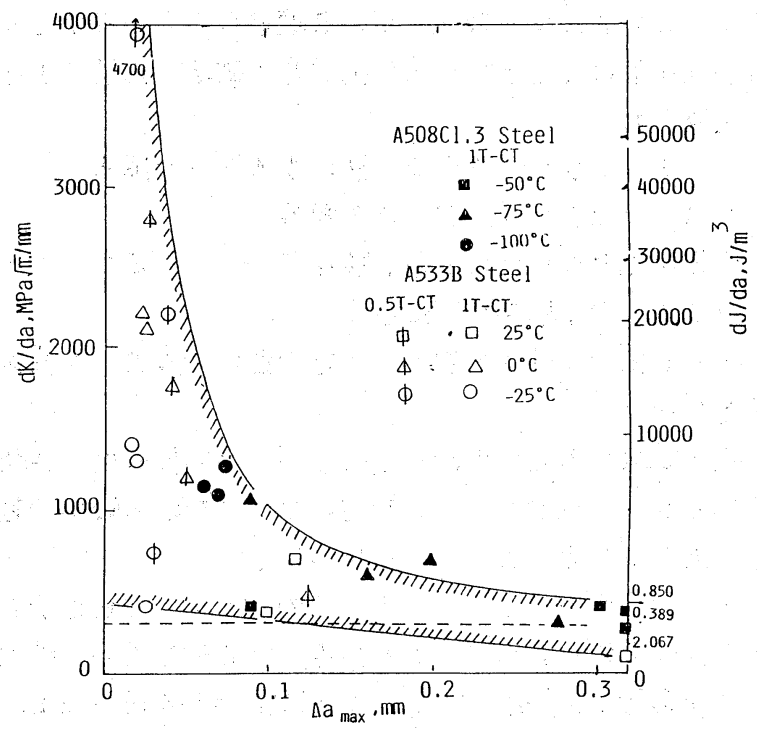

Fig. 9. Relationship between $d K / d a$ and $\Delta a_{\max }$.

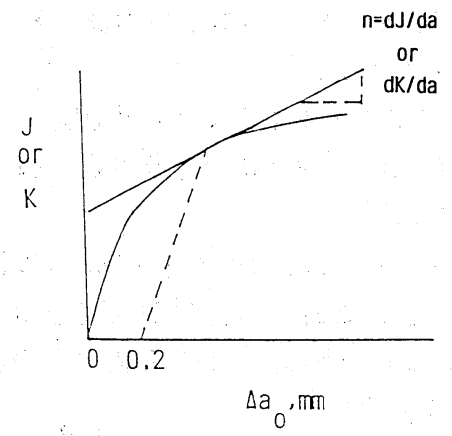

(a)

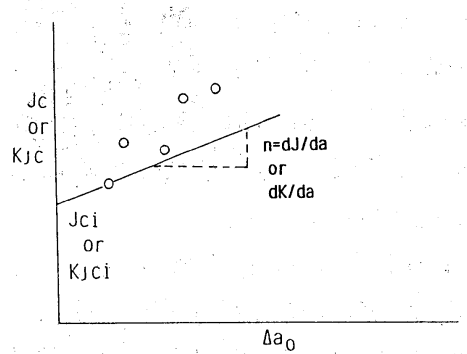

(b)

Fig. 10. Representation of the offset method using slope $n$ of $R$-curve.

いて破壊じん性破壊を行ない， $J_{C}$ と $\Delta a_{0}$ の関係あるい は $K_{J C}$ と $\Delta a_{0}$ の関係を求める.

(4) 得られた $J_{C}$ と $\Delta a_{0}$ の関係あるいは $K_{J C}$ と $\Delta a_{0}$ の 関係の図において，Fig. 10 (b) のように傾き $n$ に等しい 直線を各デー夕点を通るように引き, 縦軸との交点が最 も小さい值を示す $J_{C i}$ あるいは $K_{J C i}$ 值を破壊じん性の最 小值と定義する.

(5) ここで，上部棚温度域での $R$ 曲線の測定が不可 能な場合には, 所定の試験温度において, 除荷コンプラ イアンス法を用いて， $J-R$ 曲線あるいは $K-R$ 曲線を逐 次計測しながら試験片を荷重し破壊させる。

(6) Fig. 11 に示すように，J-R 曲線に対して一定の 
傾き $n=400 \mathrm{~J} / \mathrm{m}^{3}$ を持つ直線，あるいは $K-R$ 曲線に 対して等価な $n=300 \mathrm{MPa} \sqrt{\mathrm{m}} / \mathrm{mm}$ の直線を，破壊し た試験片の個々の $K_{J C}$ 点を通るように引く：

（7）これらの直線と縦軸との交点の中で，最も小さな 值を示す $J_{C}$ 值あるいは $K_{J C}$ 值を，破壊じん性の最小値 $J_{C i}$ あるいは $K_{J C i}$ と定義する。

ここで, フラクトグラフィ法およびオフセット法のデ 一夕解析方法の選定は，安定き裂の大きさによって選定 される.すなわち，安定き裂長さが最も大きい試験片の $\Delta a_{0 \max }$ が，き裂の鈍化曲線式

$$
\Delta a_{s}=\left[\left(1-\nu^{2}\right) / 2 \sigma_{y} E\right] K_{J C}^{2}
$$

により計算される $\Delta a_{s}$ の 2 倍以上の場合にはフラクト グラフィ法を用い， $\Delta a_{\max }$ が $2 \Delta a_{s}$ よりも小さい場合に はオフセット法を用いる.

\section{$5 \cdot 2$ オフセット法の検討}

オフセット法を適用する場合，上部棚温度域に対して $0.2 \mathrm{~mm}$ のオフセット線を引き，勾配 $n$ を求めることと しているが, この $0.2 \mathrm{~mm}$ オフセット線の妥当性につい て検討する。

Fig. 12.は 38 種類の材料の上部棚温度域での $K-R$ 曲 線において，0.1，0.2，0.3 mm のオフセット線と $K-R$ 曲線との交点で接線の傾き $n$ を求め, それぞれのオフ セット線における傾き $n$ の平均值から求めた $K_{I C i}^{\prime}$ と, 個々の材料の傾きからもとめた $K_{J C i}$ の差を $K_{J C i}$ との比

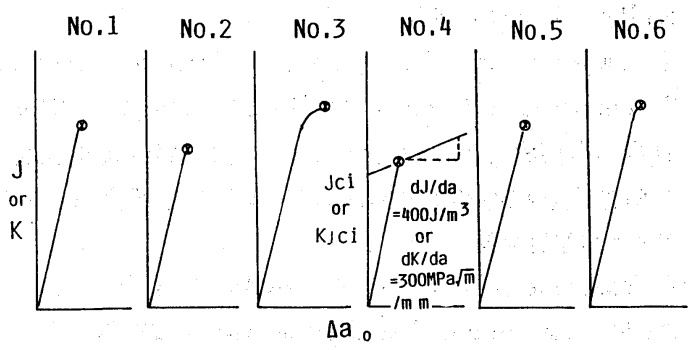

Fig. 11. Determination of lower-bound fracture toughness using the offset method.

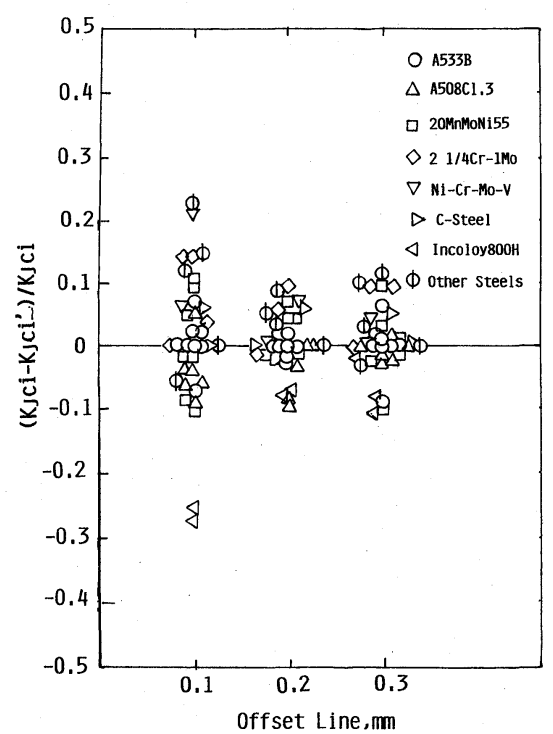

Fig. 12. $\left(K_{J C i}-K_{J C i}{ }^{\prime}\right) / K_{J C i}$ value at each offset tangent line.
で示し，“得られる破壊じん性の精度を検討したものであ る. 一定の勾配（ $n$ の平均值）を用いて求められる破壊 じん性 $K_{J C i}^{\prime}$ と個々の材料の破壊じん性 $K_{J C i}$ の差は, 0.1 $\mathrm{mm}$ のオフセット線で大きく，0.2 mm 以上のオフセッ 卜線では，ほほ等しく いる.ここで， $0.2 \mathrm{~mm}$ のオフセット線付近は，Fig. 9 から明らかなように， $R$ 曲線の安定した領域に位置し ており，測定者によって勾配 $n$ のばらつきが小さいこ とを示している.一方，Fig.7 から明らかなように，破 壊じん性の測定を対象としている試験片の $\Delta a_{0}$ の大き さは $0.2 \mathrm{~mm}$ 以下である。したがって，破壊じん性の測 定精度が良く，かつ $\Delta a_{0}$ が $0.2 \mathrm{~mm}$ より小さい場合とい うことで, $0.2 \mathrm{~mm}$ オフセット線が選定された。

つぎに，上部棚温度域での試験が不可能な場合，オフ セット法では勾配 $n$ を一定とした簡便法を使用しても 良いことを提案した。この提案は標準試験法として工業 的にだれでも簡単に同じ值を測定できるという点で，非 常に有用であり簡便さを備えている。ここで，勾配 $n$ の選定にあたっては，Fig. 12 と同様に 38 種の材料の $0.2 \mathrm{~mm}$ オフセット線によって決定された Fig. 13 に示す 勾配 $n$ の結果をもとに決定された。すなわち，破壊じ ん性の測定にあたっては，なるべく大きな勾配に設定し， すべての材料に対して保守的な值が測定されるように， デー夕解析上の配慮が必要である。この点を考慮して, Fig. 13 の結果から，K-R 曲線に対して $90 \%$ 以上が保 守的な值を与える勾配として, $n=300 \mathrm{MPa} \sqrt{\mathrm{m}} / \mathrm{mm}$ が 設定された。また $J-R$ 曲線に対しては; それと等価な $n=400 \mathrm{~J} / \mathrm{m}^{3}$ が設定された.

本研究のオフセット法は, 遷移温度域において 6 個の 試験片を用い，得られる最小の破壊じん性に対して，さ らに勾配 $n$ の接線を引いて破壊じん性の最小值 $J_{C i}$ ある いは $K_{J C i}$ を求める方法であり，かなりの高い確率で破 壊じん性の最小值を求めていることになる.

6 オフセット法により決定される $K_{J C i}$ と 大形試験片の $\boldsymbol{K}_{I C}$ との比較

Fig. 14 および Fig. 15 は，A533B 鋼および A470Ni - $\mathrm{Cr}-\mathrm{Mo}-\mathrm{V}$ 鋼において，オフセット法を用いて得られ た $K_{J C i}$ 值と ASTM E399により得られた大形試験片の 有効な $K_{I C}$ 值およびフラクトグラフィ法により得られた $K_{J C i}$ 值とを比較し示したものである゙. オフセット法によ

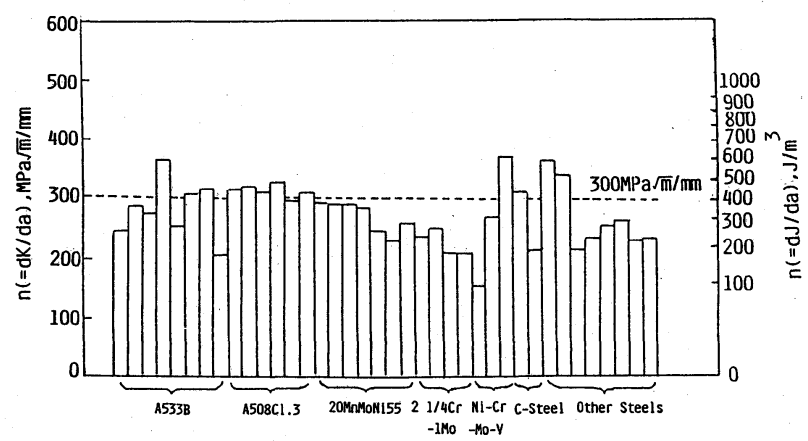

Fig. 13. Slope $n$ determined from the $0.2 \mathrm{~mm}$ stable crack growth offset tangent line. 


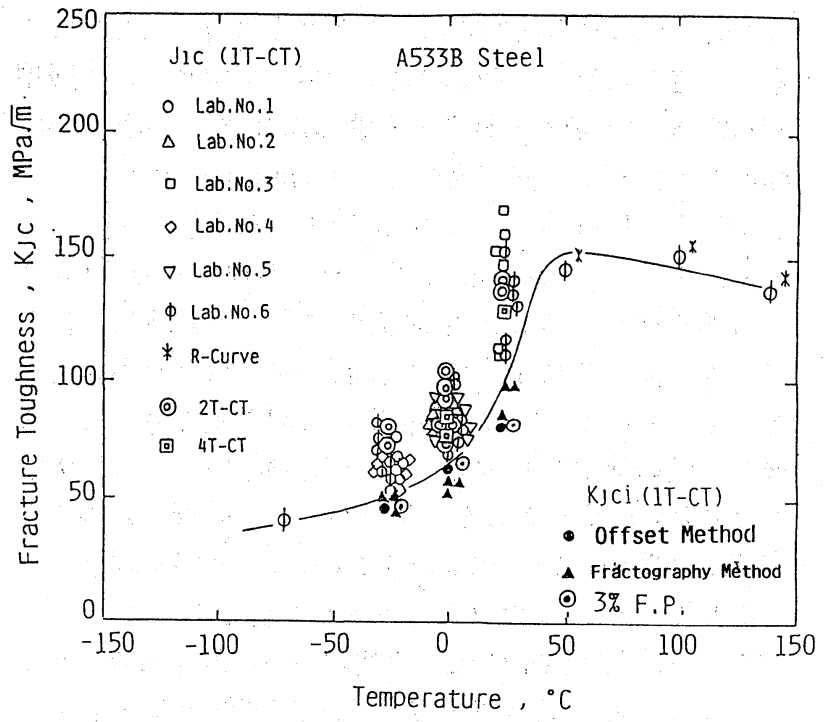

Fig. 14. Comparison of $K_{J C i}$ values obtained from the offset method and fractgraphy method and valid $K_{I C}$ values for A533B steel.

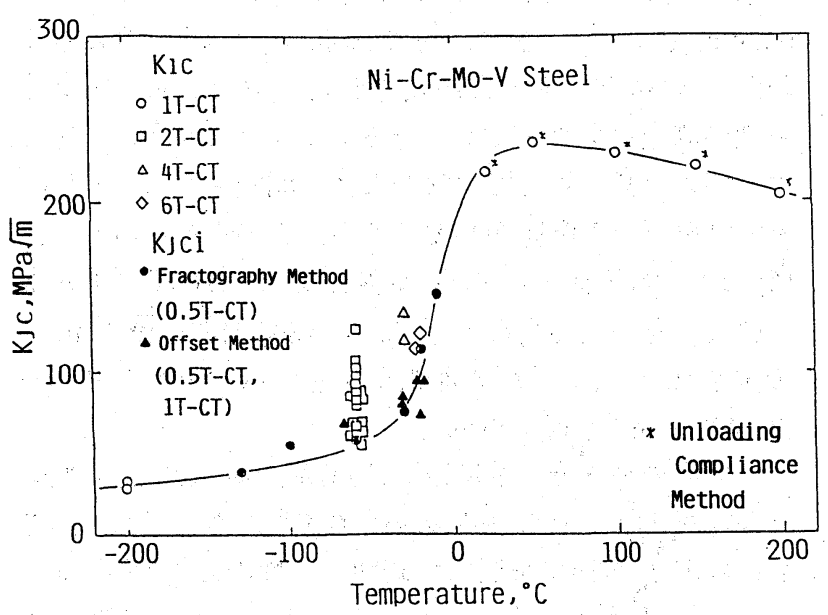

Fig. 15. Comparison of $K_{J C i}$ values obtained from the offset method and fractography method and valid $K_{I C}$ values for $\mathrm{A} 470 \mathrm{Ni}-\mathrm{Cr}-\mathrm{Mo}-\mathrm{V}$ steel.
り求められる $K_{J C i}$ 值は, フラクトグラフィ法による $K_{J C i}$ 值および大形試験片の $K_{I C}$ の下限値と良い一致を示 し，遷移温度域での破壊じん性の最小值を求める有効な 方法であることを示している。

\section{7 結 論}

本研究においては，小形試験片を用いた遷移温度域で の破壊じん性の最小值 $K_{J C i}$ を簡易的に決定する方式と して，日本学術振興会第 129 委員会の標準試験法の一つ であるオフセット法を提案し，得られる $K_{J C i}$ 值が大形 試験片による $K_{I C}$ 值と良い一致を示し，有用な標準試験 法であることを明らかにした。

本研究は日本学術振興会第 129 委員会（委員長，横堀 武夫, 東北大学名誉教授) じん性試験小委員会の共同研 究の一環として行なわれたことを記し，関係各位に謝意 を表する.

（平成 7:年 9 月 27 日 : 日本材料学会第 8 回破壊力学シンポジウムにて講 演)

\section{参 考 文 献}

1) J. D. Landes and D. H. Shaffer, Fracture Mechanics: Twelfth Conference, ASTM STP700, 368 (1980).

2 ) D. E. McCabe and J. D. Landes, Scientific Paper 83-ID7 -METEN-P3, Westinghouse Electric Corp. (1983).

3) T. Iwadate, Y. Tanaka, S. Ono and J. Watanabe, Elastic -Plastic Fracture: Second Symposium, Vol. II, ASTM STP803, II-531 (1983).

4) T. Iwadate and T. Yokobori, Fracture Mechanics: Twenty-Fourth Volume, ASTM STP1207, 233 (1994).

5 ) 日本学術振興会第129委員会基準「延性-脆性遷移温度域で の脆性破壊靱性標準試験法」, 日本学術振興会先端材料強 度第129委員会編（1995）

6 ) J. Watanabe, T. Iwadate, Y. Tanaka, T. Yokobori and K. Ando, Engineering Fracture Mechanics, 28, No. 5/6, 589 (1987).

7 ) 田中泰彦, 渡辺十郎, 岩舘忠雄, 日本機械学会論文集, A -499, 557 (1988). 